\title{
REFLEXÕES SOBRE A ESCRITA, METODOLOGIA E TEORIA DA HISTÓRIA ${ }^{1}$ REFLECTIONS ON WRITING, THEORY AND METHODOLOGY OF HISTORY
}

CAPÍTULOS DE HISTÓRIA: o trabalho com fontes. Curitiba: Aymará Educação, 2012, p.175. GUIMARÃES, Marcella Lopes.

\author{
ELAINE CRISTINA SENKO \\ Doutoranda PPGH-PR \\ Universidade Federal do Paraná \\ Curitiba, Paraná, Brasil \\ elainesenko@hotmail.com
}

Verificamos, nos últimos anos, um notável crescimento da produção acadêmica brasileira que se dedica ao estudo da teoria da história, a saber, como devemos pensar e escrever sobre os acontecimentos do passado. De fato, nossa disciplina possui a qualidade da renovação: teorias, metodologias e técnicas diferentes estão sempre surgindo, tendo em vista que cada novo momento histórico ocasiona uma nova dinâmica no campo intelectual. No entanto, notamos que grande parte desses trabalhos apresentam uma narrativa densa e uma linguagem excessivamente técnica, o que acaba restringindo o público leitor de tais obras. Dessa forma, muitos estudantes e professores, que não sejam propriamente dito "especialistas" na área, veem-se privados de grande parte desse importante conhecimento à disciplina histórica. Porém, interessantes inovações no campo da escrita estão surgindo e alterando gradualmente esse panorama. Uma obra que, nesse sentido, contribui para alargar o campo de recepção da teoria da historiografia, mantendo o nível de excelência da escrita e pensamento acadêmicos, é Capítulos de História: o trabalho com fontes (2012), de Marcella Lopes Guimarães. Graduada e Mestre em Letras pela Universidade Federal do Rio de Janeiro, Doutora em História pela Universidade Federal do Paraná, a autora apresenta, ao longo dos cinco capítulos de sua obra, uma série de orientações, do ponto de vista teórico e metodológico, para aqueles que desejam analisar fontes e iniciar uma pesquisa histórica.

O capítulo inicial da obra intitula-se Do Livro de cozinha da infanta D. Maria de Portugal às receitas eletrônicas: o sabor e saber no tempo, momento em que a autora ressalta

\footnotetext{
${ }^{1}$ Resenha submetida à avaliação em 07/10/2012 e aprovado para publicação em 27/11/2012.
} 
o fato da cultura alimentar de uma época ser um importante objeto de investigação para os historiadores, pois é um indicio revelador dos costumes, práticas e preferências dos homens e mulheres do passado. No sentido de exemplificar tal questão, Guimarães recorre a uma documentação do século XVI, o Livro de cozinha da infanta D. Maria de Portugal, apontando que os ingredientes e temperos de tais receitas podem ser considerados indicativos dos sabores buscados pela sociedade daquela época. Como um dos seus exemplos, a autora aponta que, na receita da "Galinha Mourisca", presente no livro da referida infanta "(...) sobressaem os temperos, em especial a hortelã, bastante apreciada entre os muçulmanos" (GUIMARÃES, 2012, p.28). Paralelamente à sua observação do passado, a autora provoca o leitor a avaliar os gostos e as sensações do seu próprio presente, o qual se faz marcar de modo intenso pela cultura alimentar do fast /slow food.

O capítulo seguinte, $O$ que revelam nossos álbuns de família?, instiga o leitor a observar atentamente as fotografias que possui em casa, as quais devem ser consideradas também reveladoras fontes históricas. Para Guimarães, os registros fotográficos (e as artes visuais) imprimem a passagem do tempo e podem assinalar o fluxo de mudanças nos comportamentos e ações das pessoas; pois, para a autora, "Os primeiros fotógrafos tiveram de confrontar desafios científicos dos quais hoje estamos libertos" (GUIMARÃES, 2012, p.49). Como exemplo, a autora apresenta uma série de fotos, dentre as quais está o registro da neve em Curitiba, em 1975 - um acontecimento singular.

No terceiro capítulo da obra, Crônicas de jornal e crônicas régias: a transformação de um gênero histórico, Guimarães coloca em seu foco de análise o modelo narrativo cronístico. Em sua reflexão, a autora volta-se para a Idade Média com o intuito de apontar a transformação que as crônicas literárias atuais demonstram em relação às crônicas históricas medievais. Como exemplo do passado, Guimarães apresenta uma crônica composta no século XIV intitulada Crónica del rey D. Pedro y del rey D. Henrique su hermano hijos del rey D. Alfonso onceno, escrita por Pero Lopez de Ayala (1332-1407). Uma obra como essa, cuja característica principal era a narrativa organizada por datas, deve ser vista, segundo a autora, como um importante resquício para se analisar as atitudes mentais do passado. Ora, para Guimarães, o homem é o espectador das transformações históricas: "É irresistível muitas vezes apontar para o que nos aproxima, para as continuidades e para as analogias que provariam que o homem é o mesmo, no caso da crônica, o narrador como espectador do mundo" (GUIMARÃES, 2012, p.85).

O caráter interdisciplinar atribuído pela autora a sua obra está claramente presente no quarto capítulo, História e Literatura: um debate desde Aristóteles, no qual se faz indicar 
como a História e a Literatura travam um embate entre o verdadeiro e o verossímil (possível). Para essa discussão, Guimarães tem por apoio a obra Arte Poética, de Aristóteles, autor que atribui uma perspectiva universal para a Literatura e particular à História. Guimarães demonstra que a escrita historiográfica modificou-se sensivelmente ao longo do tempo - de Heródoto até os dias de hoje -, e que nela podemos perceber uma vinculação direta para com a Literatura. Conforme suas próprias palavras, "A Literatura exercita possibilidades, como previra o estagirita" (GUIMARÃES, 2012, p.119). Como exemplo para a discussão dessa questão, a autora apresenta uma reflexão tendo por base o livro do escritor português José Saramago, História do cerco de Lisboa, de 1989, o qual possui duas partes definidas: a histórica e a fictícia. Com relação a essa obra de Saramago, Guimarães ressalta justamente a contribuição da ação literária no sentido de estimular a problematização da História.

No quinto e último capítulo da obra, Notas sobre possibilidades de trabalho com fontes não escritas, Guimarães ressalta que a investigação histórica, em sua escolha documental, deve continuar cada vez mais se utilizando da cultura material na busca de informações sobre o passado. De fato, Guimarães chama a nossa atenção para a grande quantidade de fontes materiais que temos à nossa volta, espalhadas por nossos centros urbanos. Museus, praças, monumentos, prédios históricos são locais que, por sua historicidade, devem ser frequentados e analisados pelo historiador. Como exemplos nesse sentido, Guimarães traz imagens do Alcácer de Sevilha e da Mesquita Catedral de Córdoba (arquiteturas situadas na atual Espanha), monumentos que, por sua beleza, suscitam nosso interesse e estimulam nosso desejo pelo conhecimento do passado. Portanto, para a autora, "Inúmeras são hoje as possibilidades de trabalho histórico quando convocamos a cultura material, ou seja, quando convocamos os vestígios materiais, concretos, com os quais os grupos humanos fizeram sua vida" (GUIMARÃES, 2012, p.143).

A leitura de Capítulos de História: o trabalho com fontes, competente trabalho da historiadora Marcella Lopes Guimarães, é uma experiência que instiga o público leitor a querer investigar sobre o passado, uma tarefa que se torna possível graças ao recurso às diversas categorias de fontes históricas que dispomos perto de nós: seja dentro de casa (utensílios/livros antigos e álbuns de fotografia da família) ou no espaço público de nossa cidade (museus e monumentos). Guimarães realiza o paralelo passado/presente ao longo de toda sua obra, demonstrando que a fonte motivadora para o estudo do historiador são as questões de seu próprio tempo, seguindo, dessa forma, a importante perspectiva de Marc Bloch. Todas as ideias da autora são apresentadas em uma narrativa muito agradável; ademais, no canto lateral das páginas, foram colocados pequenos textos explanativos sobre 
determinados termos ou acontecimentos/pessoas que foram mencionados. Nesse sentido, a obra ganha em valor didático. E é provavelmente pensando nisso que a autora apresenta, ao final de cada capítulo, sugestões de atividades a serem desenvolvidas pelos professores de História junto aos seus alunos. Portanto, para todos aqueles que demonstram interesse pela investigação e conhecimento do presente e do passado, acadêmicos ou não, a obra de Marcella Lopes Guimarães é uma considerável recomendação, pois ela cumpre muito bem com seu papel de estimular a crítica e a reflexão no público leitor da atualidade. 